\title{
PHYSICAL MODEL TESTS ON WAVE OVERTOPPING AND FLOW PROCESSES ON DIKE CRESTS INFLUENCED BY WAVE-CURRENT INTERACTION
}

\author{
Stefanie Lorke' ${ }^{1}$, Babette Scheres ${ }^{1}$, Holger Schüttrumpf ${ }^{1}$, Antje Bornschein $^{2}$, \\ Reinhard Pohl ${ }^{2}$
}

\begin{abstract}
Flow processes like flow depths and flow velocities give important information about erosion and infiltration processes, which can lead to an unstable dike structure and consequently to dike failure. Up to now several physical model tests on wave run-up and wave overtopping are available to adjust and improve design formula for different dike structures. This kind of physical model tests have been performed in the here presented project FlowDike. Its main purpose is to consider two new aspects that could influence the assessment of wave run-up and wave overtopping as well as the flow processes on dikes which have not been investigated yet: longshore current and wind. Especially in estuaries and along coasts, the effect of tidal and storm induced currents combined with local wind fields can influence the incoming wave parameters at the dike toe as well as the wave run-up height, the wave overtopping rate and the flow processes on dikes. This paper will focus on these flow processes on dike slopes and dike crests on an 1:6 sloped dike influenced by oblique wave attack and longshore current.
\end{abstract}

Keywords: flow processes; layer thickness; dike slope; dike crest; wave overtopping; physical model test; wave; current; dike; EurOtop-Manual

\section{INTRODUCTION}

Coastal and estuarine dikes are designed on the basis of design water levels and incoming wave conditions. High waves combined with low freeboard heights can result in wave overtopping and subsequently in dike failures. Additional factors such as the angle of wave attack or the roughness of a dike have to be considered for wave run-up and wave overtopping (EurOtop-Manual, 2007). Furthermore a longshore current in front of the defence structure, like the tidal current, could have an influence on wave run-up, wave overtopping and flow processes on dike crests.

In order to investigate these processes - influence of a longshore current on wave run-up, wave overtopping and flow processes on dike crests - physical model tests were performed at the Danish Hydraulic Institute (DHI) in Hørsholm (Denmark) in small scale in 2009 (project FlowDike: Hydralabproject HyIII-DHI-5 and KFKI-project 03KIS075 (RWTH Aachen University) and 03KIS076 (TU Dresden)). The model set-up and results on wave run-up and wave overtopping are presented in Lorke et al. (2012).

Investigations on overtopping flow processes for different dike slopes and freeboard heights as well as dike roughnesses have been investigated in detail by Schüttrumpf \& van Gent (2003) and Bosman (2007). The spatial effects like the influence of oblique wave attack and/or a longshore current on wave overtopping parameters like flow processes on dike crests have not been investigated yet.

This paper will concentrate on the results of flow depths on the 1:6 sloped dike.

\section{EXPERIMENTAL SET-UP}

The basin of the DHI has a length of $35 \mathrm{~m}$ and a width of $25 \mathrm{~m}$. For the model tests the dike out of concrete with a length of $26.5 \mathrm{~m}$ was divided lengthwise into two parts: one part with a crest height of $0.60 \mathrm{~m}$, the other part with a crest height of $0.70 \mathrm{~m}$. The model tests have been divided into two tests phases. The main difference was the dike slope of $1: 3$ and $1: 6$. The water depth was $0.50 \mathrm{~m}$ during the first test phase and $0.55 \mathrm{~m}$ during the second test phase. With a $16 \mathrm{~m}$ long multidirectional wave generator irregular long crested waves (Jonswap spectrum) were generated for different angles of wave attack up to $45^{\circ}$, thereby perpendicular wave attack is defined as $0^{\circ}$. A longshore current up to $0.40 \mathrm{~m} / \mathrm{s}$ was generated along the dike line. The wave run-up height was measured with a wave run-up board. The wave overtopping amount was collected in overtopping tanks which have been weighted by load cells. Figure 1 gives an overall view of the model set-up along the dike line.

\footnotetext{
${ }^{1}$ Institute for Hydraulic Engineering and Water Resources Management (IWW), RWTH Aachen University, Mies-vander-Rohe-Strasse 1, 52056 Aachen, Germany; lorke@iww.rwth-aachen.de; babette.scheres@rwth-aachen.de; schuettrumpf@iww.rwth-aachen.de

${ }^{2}$ Institute of Hydraulic Engineering and Technical Hydromechanics (IWD), TU Dresden, 01062 Dresden, Germany; antje.bornschein@tu-dresden.de; Reinhard.Pohl@tu-dresden.de
} 


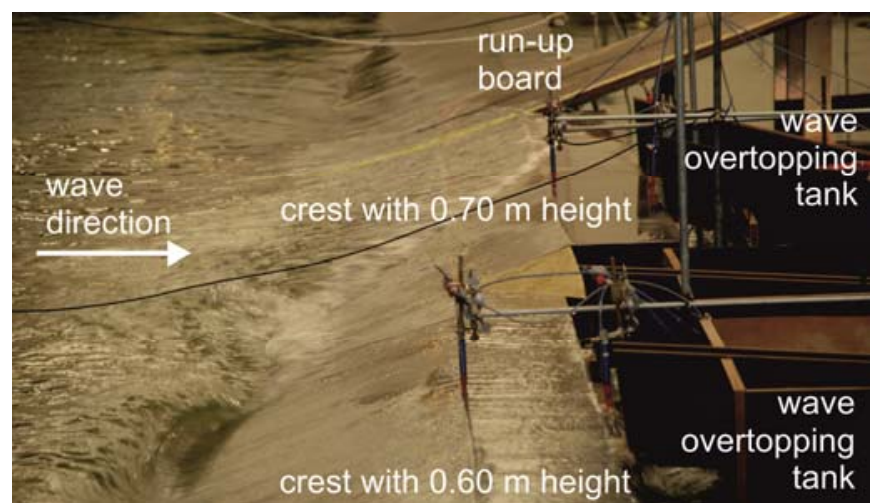

Figure 1. View along the dike line of the model set-up.

The measurement of flow processes on dike crests required the following instruments:

- wave gauges to measure the flow depth $h$

- micro propellers to measure the flow velocity $\mathrm{u}$

Each instrument was installed on the seaward and on the landward side of each dike crest. Furthermore, a wave gauge was installed on the slope during the tests on the 1:6 sloped dike. Figure 2 (left) shows an overtopping process near the inlet to an overtopping tank and the measuring devices on the dike crest. Figure 2 (right) shows the measuring devices on the dike crest in a more detailed perspective.
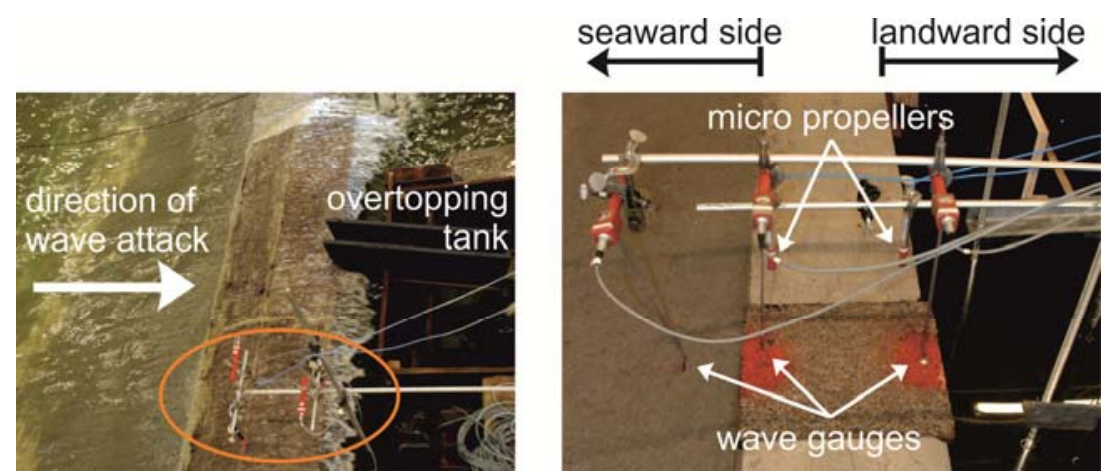

Figure 2. Measurements on the dike crest.

The positions of measuring devices are illustrated schematically in top view in Figure $3 \mathrm{a}$. The chosen installation permitted to measure the processes of flow depths and flow velocities on the dike crest.

The flow velocities have been measured with micro propellers by Schiltknecht (cf. Figure $3 b$ ). These devices have a vane rotation that is closely linear to flow velocity and unaffected by pressure, temperature, density or humidity. The measuring range of the propellers varies between $0.04 \mathrm{~m} / \mathrm{s}$ and $5 \mathrm{~m} / \mathrm{s}$ with an accuracy of $2 \%$ of the full scale. Flow depths have been measured by wave gauges (cf. Figure 3c). A change of conductivity between two thin, parallel stainless steel electrodes of a wave gauge can be detected and converted into flow depth.

The devices on the dike crest were situated $0.03 \mathrm{~m}$ from each crest edge, so a distance of $0.24 \mathrm{~m}$ was kept between the aligned seaward and landward measurements. Moreover, the flow depths on the dike slope were measured by additional wave gauges which were placed at a horizontal distance of $0.12 \mathrm{~m}$ downstream the crest edge of the two different dike heights (cf. Figure 3). 


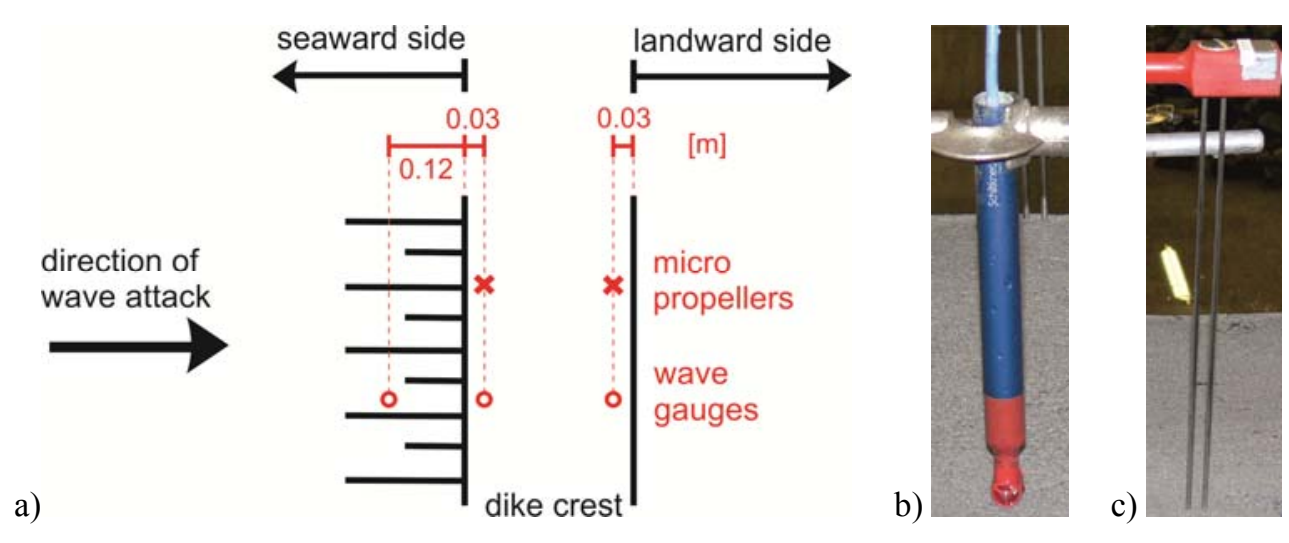

Figure 3. a) Measurements on the dike crest (schematically); b) micro propeller; c) wave gauge.

\section{TEST PROGRAMM}

The main difference of the two tests phases was the dike slope of 1:3 and 1:6. During both test phases the following boundary conditions have been kept constant:

- long crested waves under a Jonswap spectrum (one test included 1'000 waves) with active wave absorption

- two freeboard heights $\mathrm{R}_{\mathrm{c}}[\mathrm{m}]$ (1:3 sloped dike: $0.10 \mathrm{~m}, 0.20 \mathrm{~m} ; 1: 6$ sloped dike: $0.05 \mathrm{~m}, 0.15 \mathrm{~m}$ )

- dike roughness (concrete)

- dike geometry

During the tests the following boundary conditions have been varied, to determine their influence on wave run-up, wave overtopping and flow processes:

- wave parameters (significant wave height $\mathrm{H}_{\mathrm{s}}[\mathrm{m}]$ and peak period $\mathrm{T}_{\mathrm{p}}[\mathrm{s}]$ )

- angle of wave attack $\beta\left[^{\circ}\right]$ (perpendicular wave attack: $\beta=0^{\circ}$; wave attack with the current: $\beta>0^{\circ}$; wave attack against the current: $\left.\beta<0^{\circ}\right)$

- longshore current velocity $\mathrm{v}_{\mathrm{x}}[\mathrm{m} / \mathrm{s}]$

- wind velocity $\mathrm{u}[\mathrm{m} / \mathrm{s}]$ perpendicular to the dike line

Each test series contained six tests with different sea states. Whereas, angle of wave attack, longshore current velocity and wind velocity have been kept constant. The approached wave heights and wave periods are given in Table 1 for both test phases. A matrix of the different test configurations is given in Figure 4. Extensive tables with all tests and their boundary conditions are given in Lorke (2012). In total 119 tests were performed on an 1:3 sloped dike and 152 tests were done on an 1:6 sloped dike.

\begin{tabular}{|c|c|c|c|c|}
\hline & \multicolumn{2}{|c|}{ 1:3 sloped dike } & \multicolumn{2}{|c|}{ 1:6 sloped dike } \\
\hline & $\mathrm{H}_{\mathrm{s}}[\mathrm{m}]$ & $\mathrm{T}_{\mathrm{p}}[\mathrm{s}]$ & $\mathrm{H}_{\mathrm{s}}[\mathrm{m}]$ & $\mathrm{T}_{\mathrm{p}}[\mathrm{s}]$ \\
\hline sea state 1 & 0.07 & 1.474 & 0.09 & 1.670 \\
\hline sea state 2 & 0.07 & 1.045 & 0.09 & 1.181 \\
\hline sea state 3 & 0.10 & 1.760 & 0.12 & 1.929 \\
\hline sea state 4 & 0.10 & 1.243 & 0.12 & 1.364 \\
\hline sea state 5 & 0.15 & 2.156 & 0.15 & 2.156 \\
\hline sea state 6 & 0.15 & 1.529 & 0.15 & 1.525 \\
\hline
\end{tabular}


1:3 sloped dike

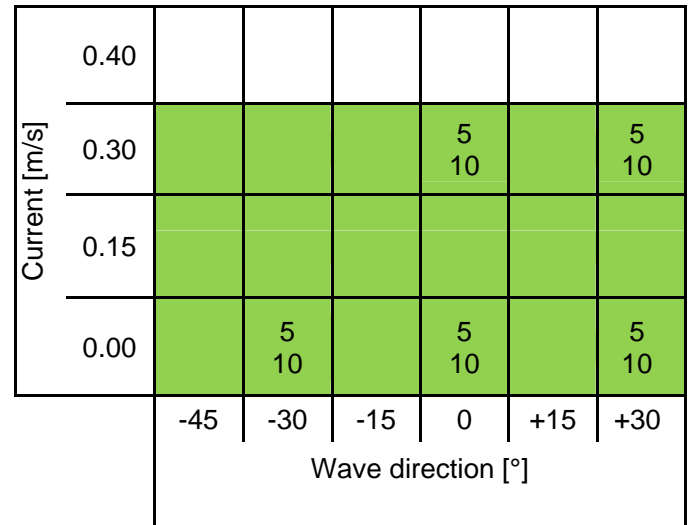

1:6 sloped dike

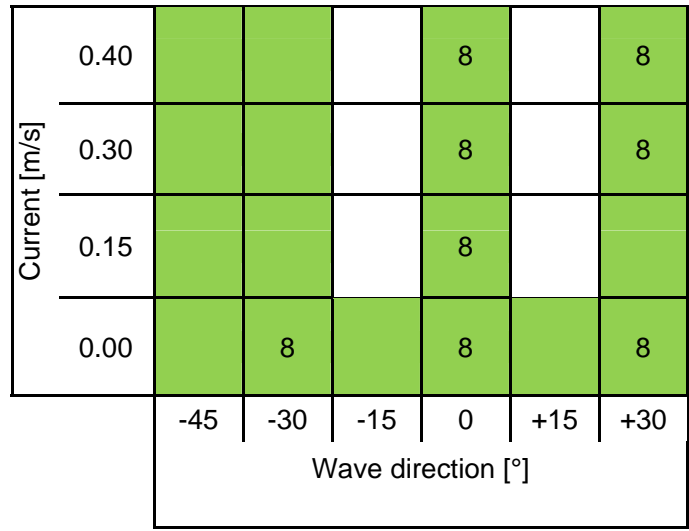

Figure 4. Matrix of the conducted test series on the 1:3 sloped dike (left) and on the 1:6 sloped dike (right) (tests regarding the influence of wind are marked by the value of the wind velocity $[\mathrm{m} / \mathrm{s}]$ in the cell; $\square=$ tests were not carried out, $\square=$ tests were carried out) (modified according to Lorke (2012)).

\section{STATE OF THE ART}

Flow processes on dikes were analysed by Schüttrumpf (2001) and van Gent (2002) in several model studies. Therein, different dike geometries - i. e. a variation of dike slope and crest height - were investigated as well as several roughnesses of dikes. Both investigations have been brought together (Schüttrumpf \& van Gent, 2003). Bosman et al. (2008) used the raw data of Schüttrumpf (2001) and van Gent (2002) and analysed them using a new approach. For each part of the dike (seaward slope, dike crest and landward slope) formulae to describe the flow depth have been determined and verified. Schüttrumpf (2001) describes the flow depth on the seaward slope $\mathrm{h}_{2 \% \text {,slope }}$ by the following formula:

$$
\mathrm{h}_{2 \% \text { slope }}=0.035 \cdot \mathrm{x} *
$$

with $\mathrm{h}_{2} \%$ flow depth on dike slope which is exceeded by $2 \%$ of the incident waves [m]

$\mathrm{x}^{*} \quad$ geometric parameter: $\mathrm{x} * \mathrm{x}_{\mathrm{Z}}-\mathrm{x}_{\mathrm{A}}[\mathrm{m}]$

$\mathrm{x}_{\mathrm{Z}} \quad$ horizontal distance from still water level (SWL) to run-up [m]

$\mathrm{x}_{\mathrm{A}} \quad$ horizontal distance from SWL to considered point on dike slope A [m]

The used parameters of equation (1) are illustrated in Figure 5.

$$
x^{*}=x_{z}-x_{A}
$$

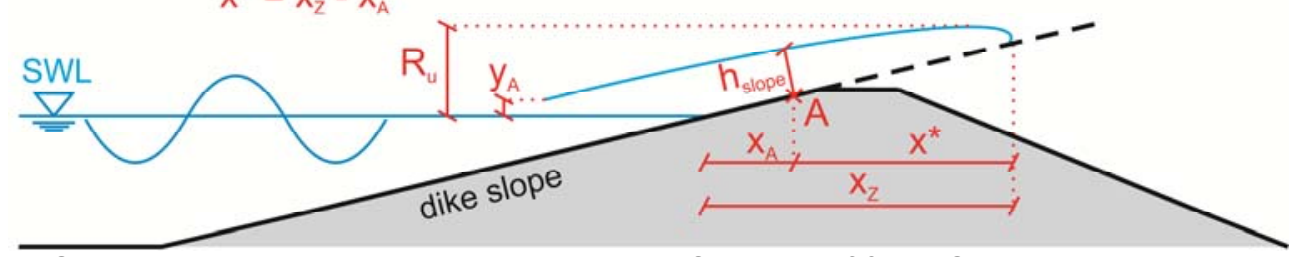

Figure 5. Geometrical parameters on dike slopes used by Schüttrumpf \& van Gent (2003).

The flow processes along the dike crest can be described by the formula given by Schüttrumpf $\&$ van Gent (2003):

$$
\frac{\mathrm{h}_{2 \% \text {,land }}\left(\mathrm{x}_{\mathrm{C}}\right)}{\mathrm{h}_{2 \% \text {,ea }}\left(\mathrm{x}_{\mathrm{C}}=0\right)}=\exp \left(-\mathrm{c}_{\mathrm{C}, \mathrm{h}} \frac{\mathrm{x}_{\mathrm{C}}}{\mathrm{B}_{\mathrm{C}}}\right)
$$

with $\mathrm{h}_{2 \% \text {,land }} \quad$ flow depth on landward crest which is exceeded by $2 \%$ of the incident waves [m] $\mathrm{h}_{2 \% \text {,sea }} \quad$ flow depth on seaward crest which is exceeded by $2 \%$ of the incident waves [m]

$\mathrm{x}_{\mathrm{c}} \quad$ horizontal distance from the beginning of crest to considered location on dike crest $[\mathrm{m}]$

$\mathrm{B}_{\mathrm{C}} \quad$ crest width [m]

$\mathrm{c}_{\mathrm{C}, \mathrm{h}} \quad$ empirically determined coefficient [-]

In Figure 6 the parameters of the previous equation are illustrated. The coefficient $\mathrm{c}_{\mathrm{C}, \mathrm{h}}$ has to be determined for each different model set-up. Schüttrumpf (2001) specified $\mathrm{c}_{\mathrm{C}, \mathrm{h}}=0.89$ for a 1:6 sloped dike and van Gent (2002) $\mathrm{c}_{\mathrm{C}, \mathrm{h}}=0.4$ for a 1:4 sloped dike. 


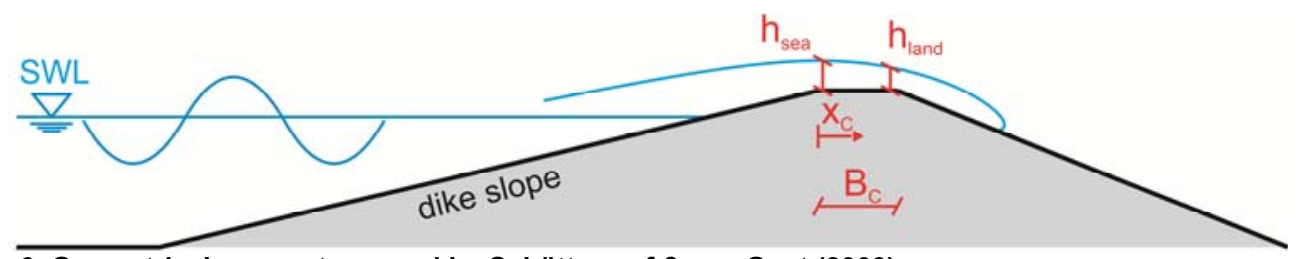

Figure 6. Geometrical parameters used by Schüttrumpf \& van Gent (2003).

Bosman et al. (2008) defined formulae to describe the flow processes on dike crests using the data of Schüttrumpf (2001) and van Gent (2002). Therefore, a further coefficient $c_{\text {trans, h }}$ has been introduced. With this coefficient the decrement of flow depth due to the transition from the outer slope to the horizontal crest is considered. Another difference to the formulae of Schüttrumpf \& van Gent (2003) (cf. equation (2)) is the correlation of the horizontal distance to the seaward crest $\mathrm{x}_{\mathrm{C}}$ to the wave length $\mathrm{L}_{0}$.

$$
\frac{h_{2 \%, \text { land }}\left(x_{C}\right)}{h_{2 \%, \text { sea }}\left(x_{C}=0\right)}=c_{\text {trans }, h} \cdot \exp \left(-c_{C, h} \frac{x_{C}}{\gamma_{f-C} L_{0}}\right)
$$

with $\mathrm{L}_{0} \quad$ wave length [m]

$\gamma_{\mathrm{f}-\mathrm{C}} \quad$ friction factor on the crest ( 1 for a smooth surface) [-]

$c_{\text {trans, }}$ empirical determined coefficient to consider the influence due to transition [-] (2008).

For the 1:6 sloped dike the coefficient $c_{\text {trans,h }}$ was determined as 0.81 and $\mathrm{c}_{\mathrm{C}, \mathrm{h}}$ as 6 by Bosman et al.

\section{EVALUATION OF FLOW PROCESSES ON DIKES}

Dike slope

During Project FlowDike the flow depths on the slope have been measured $0.03 \mathrm{~m}$ and $0.13 \mathrm{~m}$ above still water level on the 1:6 sloped dike. Analysing these measurements, the data is comparable to the recommended formula (1). Figure 7 shows the comparison of the measured data (red and blue dots) to the graph presented by Schüttrumpf (2001) (orange line).

The measurements of the wave gauge that is installed $0.13 \mathrm{~m}$ above SWL correspond well to Schüttrumpf (2001). The formula by Schüttrumpf (2001) underestimates the flow depths measured $0.03 \mathrm{~m}$ above SWL. This leads to the presumption, that the flow depths of the run-up flow do not follow a linear variation.
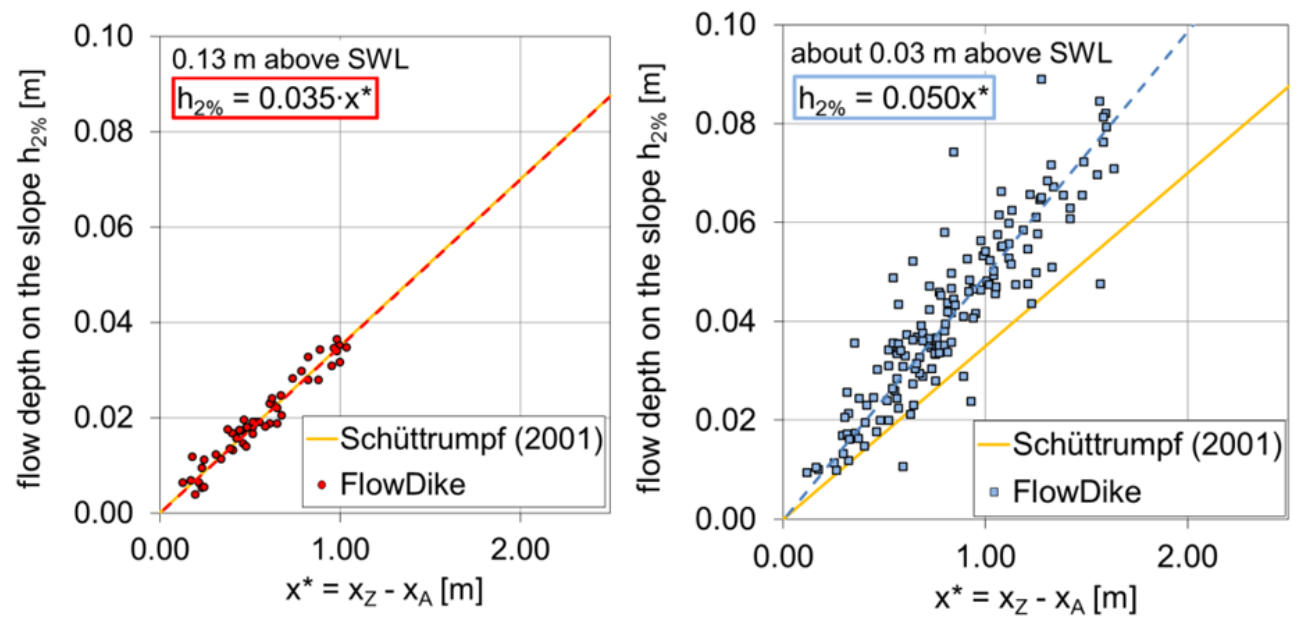

Figure 7. Flow depth on the dike slope $0.13 \mathrm{~m}$ above SWL (left) and $0.03 \mathrm{~m}$ above SWL (right).

Therefore, a non-linear relationship of the flow depth along the dike slope has to be considered and a new geometric parameter $x$ ' has been determined. Its definition is given in the following formula:

$$
\mathrm{x}^{\prime}=\left(\mathrm{x}_{\mathrm{z}}-\mathrm{x}_{\mathrm{A}}\right) \cdot \frac{\mathrm{R}_{\mathrm{u} 2 \%}-\mathrm{y}_{\mathrm{A}}}{\mathrm{R}_{\mathrm{u} 2 \%}}
$$

with $\mathrm{x}_{\mathrm{Z}} \quad$ horizontal distance from SWL to run-up [m]

$\mathrm{x}_{\mathrm{A}}$ horizontal distance from SWL to the considered point A on dike slope [m] 
$\mathrm{R}_{\mathrm{u} 2 \%}$ flow depth on dike slope which is exceeded by $2 \%$ of the incident waves [m]

$\mathrm{y}_{\mathrm{A}} \quad$ vertical distance from SWL to wave gauge on dike slope (cf. point A in Figure 5) [m]

A potential function has been derived to describe the relationship of the flow depth $\mathrm{h}_{2 \%}$ on the dike slope and the geometric parameter $x^{\prime}$ :

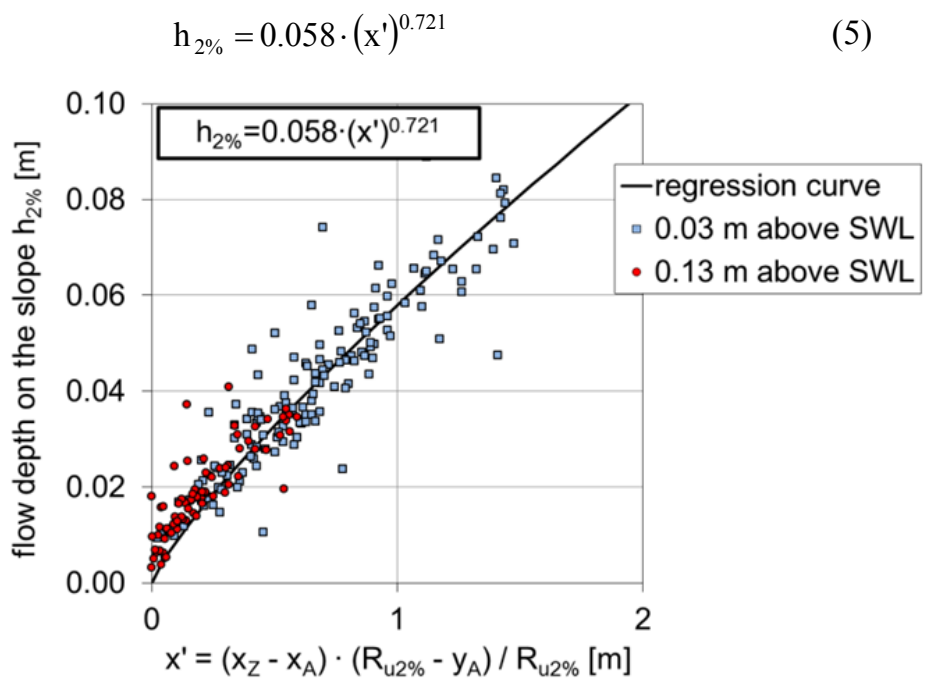

Figure 8. Flow depths on the dike slope $0.13 \mathrm{~m}$ above $\mathrm{SWL}$ and $0.03 \mathrm{~m}$ above SWL.

Dike crest

Investigating the flow depth on dike crests, first comparisons to Schüttrumpf \& van Gent (2003) were accomplished. Therefore, the coefficients of equation (2) have been derived and compared with previous results. Figure 9 shows the analysis of the 1:3 sloped dike (orange line) and 1:6 sloped dike (red line) as well as the results of Schüttrumpf (2001) and van Gent (2002) with black broken lines.

For the 1:3 sloped dike a coefficient of 0.35 and for the 1:6 sloped dike of 0.49 has been found. Although these values show a deviation from the coefficient of Schüttrumpf, a tendency within all investigations can be recognized. With a steeper dike slope the coefficient $c_{h}$ decreases and consequently the flow depth abates along the dike crest. A good approximation is given to the coefficient of van Gent for a 1:4 sloped dike, which lies between the coefficients for the 1:3 and 1:6 sloped dike. However, a deviation between the coefficient of Schüttrumpf to the other results is noticeable, because the measured flow depth by Schüttrumpf is measured on the dike slope directly at the transition from slope to crest.
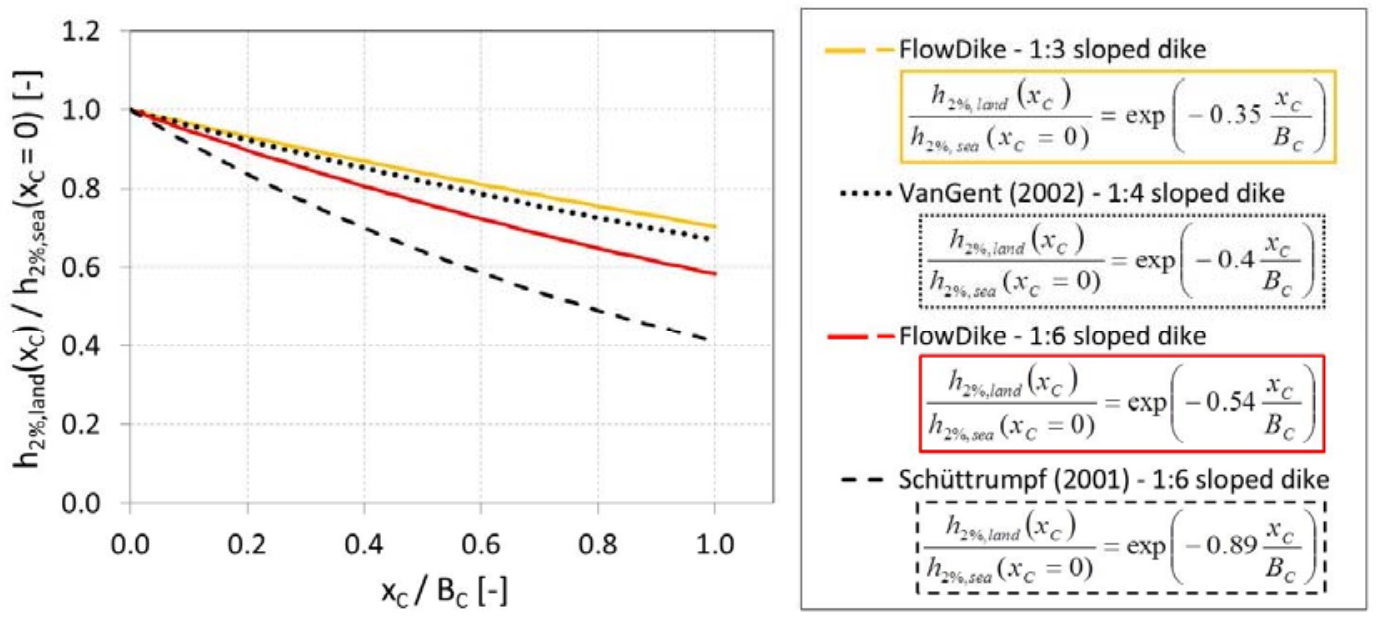

Figure 9. Flow depth on the dike crest in comparison to Schüttrumpf \& van Gent (2003).

The formula (3) by Bosman et al. (2008) amplifies the formula (2) by Schüttrumpf \& van Gent (2003) by considering the wave length. For the presented study the coefficient $\mathrm{c}_{\text {trans }}$ has been defined as constant. The coefficient $\mathrm{c}_{\mathrm{C}, \mathrm{h}}$ has been derived for the two investigated dike slopes. The results are presented in Figure 10. The higher the inclination of the dike slope the higher is the coefficient $\mathrm{c}_{\mathrm{C}, \mathrm{h}}$. 

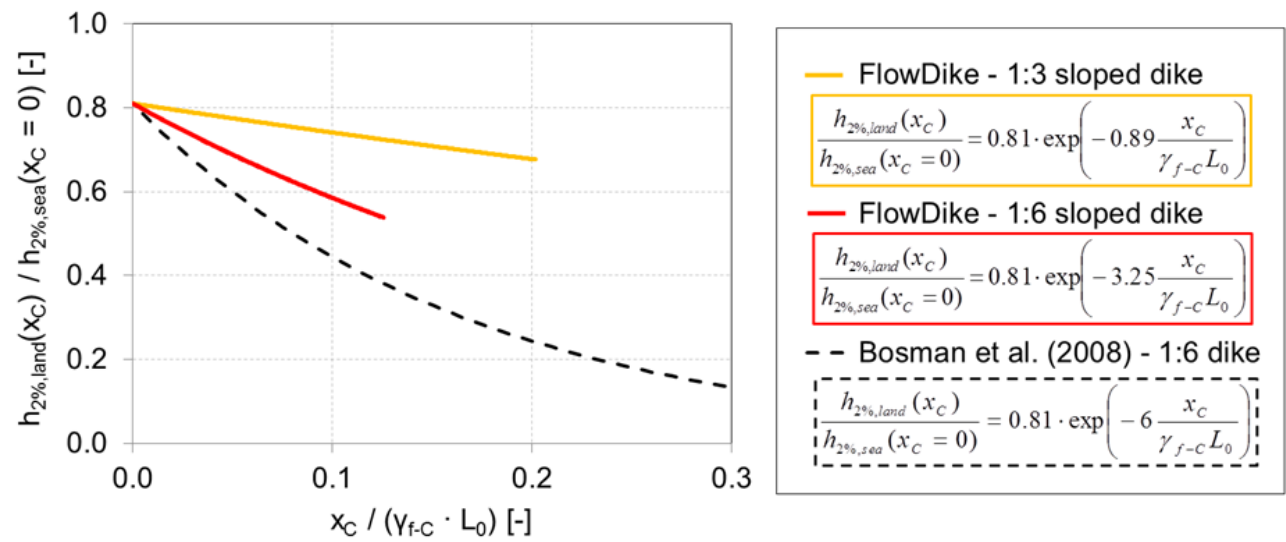

Figure 10. Flow depth on the dike crest in comparison to Bosman et al. (2008).

\section{FLOW PROCESSES ON DIKES RELATED TO MEAN WAVE OVERTOPPINGON RATES}

The flow depths have been measured at three positions: on the slope, on the seaward side and on the landward side of the dike crest. Figure 11 shows the dimensionless mean wave overtopping rate $\mathrm{q}^{*}$ against the dimensionless flow depth $\mathrm{h}_{2 \%}$ * that are defined as following for breaking wave conditions:

$$
\begin{aligned}
& \mathrm{h}_{2 \%}^{*}=\frac{\mathrm{h}_{2 \%}}{\mathrm{H}_{\mathrm{s}}} \cdot \sqrt{\frac{\mathrm{s}_{\mathrm{m}-1,0}}{\tan \alpha}} \\
& \mathrm{q}^{*}=\frac{\mathrm{q}}{\sqrt{\mathrm{g} \cdot \mathrm{H}_{\mathrm{s}}^{3}}} \cdot \sqrt{\frac{\mathrm{s}_{\mathrm{m}-1,0}}{\tan \alpha}}
\end{aligned}
$$

with $\mathrm{h}_{2 \%} \quad$ flow depth on dikes exceeded by $2 \%$ of the incoming waves [m] $\mathrm{H}_{\mathrm{s}} \quad$ significant wave height [m]

$\mathrm{s}_{\mathrm{m}-1,0} \quad$ wave steepness based on spectral wave parameters $\mathrm{H}_{\mathrm{s}}$ and $\mathrm{T}_{\mathrm{m}-1,0}[-]$

$\tan \alpha$ dike slopes [-]

$\mathrm{q} \quad$ mean wave overtopping rate $[1 /(\mathrm{sm})]$

The higher the overtopping rate is the higher is the flow depth. The spreading in dimensionless flow depths can be explained by detecting not only the wave run-up but also the run-down events of the overtopping processes. For all positions (slope, seaward, landward) a power function was applied to describe the relationship

dike slope:

seaward side of the crest:

landward side of the crest:

$$
\begin{aligned}
& \mathrm{h}_{2 \%} *=0.629 \cdot(\mathrm{q} *)^{0.248} \\
& \mathrm{~h}_{2 \%} *=0.637 \cdot(\mathrm{q} *)^{0.297} \\
& \mathrm{~h}_{2 \%} *=0.293 \cdot(\mathrm{q} *)^{0.239}
\end{aligned}
$$

The flow depths on the seaward side are, depending on the mean dimensionless wave overtopping rate, about $25 \%$ less than on the slope. The flow depths on the landward side decrease in comparison to the flow depths on the seaward side again by about $30 \%$. 


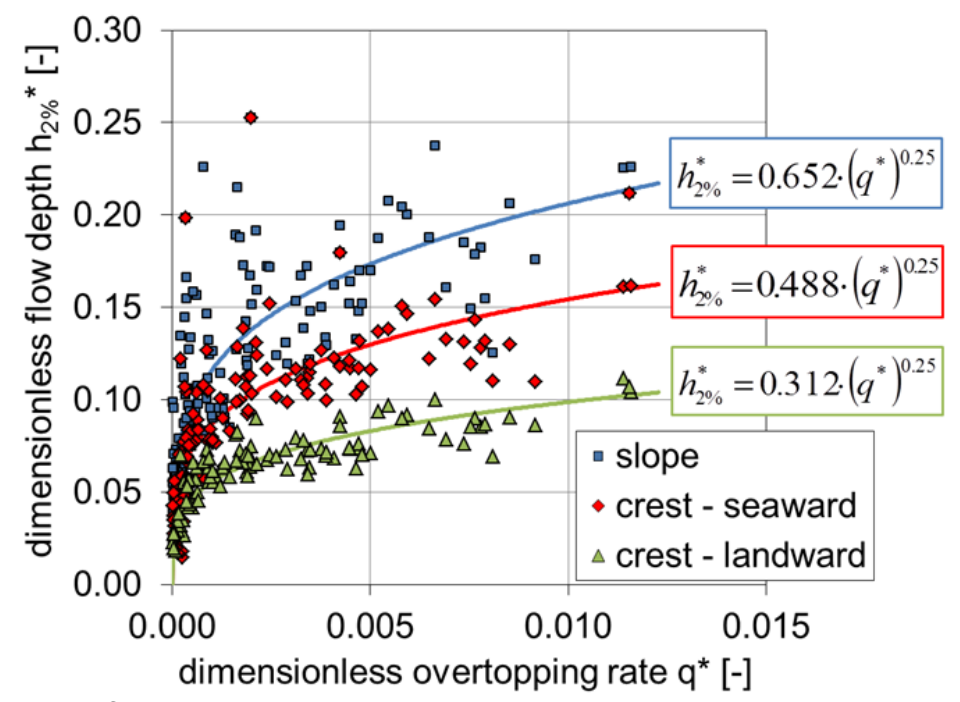

Figure 11. Dimensionless flow depth against dimensionless overtopping rate.

\section{INFLUENCE OF OBLIQUE WAVE ATTACK ON FLOW PROCESSES ON DIKES}

The analysis of the influence of oblique wave attack on flow processes on the seaward side of the dike crests will be performed by the same principle used for analysing the wave overtopping rates (cf. EurOtop-Manual 2007, Lorke 2010). Therefore, the dimensionless flow depth $\mathrm{h}_{2 \%}{ }^{*}$ on the dike (cf. formula (6)) and the dimensionless freeboard height $\mathrm{R}_{\mathrm{c}}{ }^{*}$ are determined. The dimensionless freeboard height for breaking wave conditions is given as follows:

$$
\mathrm{R}_{\mathrm{c}}^{*}=\frac{\mathrm{R}_{\mathrm{c}}}{\mathrm{H}_{\mathrm{s}}} \cdot \frac{\sqrt{\mathrm{s}_{\mathrm{m}-1,0}}}{\tan \alpha}
$$

with $\mathrm{R}_{\mathrm{c}} \quad$ freeboard height $[\mathrm{m}]$

$\mathrm{H}_{\mathrm{s}} \quad$ significant wave height $[\mathrm{m}]$

$\mathrm{s}_{\mathrm{m}-1,0} \quad$ wave steepness based on spectral wave parameters [-]

$\tan \alpha$ dike slope [-]

In Figure 12 the relative freeboard height is given on the $\mathrm{x}$-axis while the exponential $\mathrm{y}$-axis shows the relative flow depth $\mathrm{h}_{2 \%}{ }^{*}$ on the seaward side of the dike crest. The results for the 1:3 sloped dike (left) and 1:6 sloped dike (right) are given.

The reference test is shown by the blue data points with the corresponding regression curve given by the blue graph. Reference tests are carried out and analysed for perpendicular wave attack, without current and without wind but with different wave parameters. The other graphs show the results for tests with angles of wave attack of $15^{\circ}$ (red), $30^{\circ}$ (green) and $45^{\circ}$ (orange). The corresponding regression curves can be described by exponential functions:

$$
\mathrm{h}_{2 \%}^{*}=\mathrm{a}_{\mathrm{h}} \cdot \exp \left(\mathrm{b}_{\mathrm{h}} \cdot \mathrm{R}_{\mathrm{c}}^{*}\right)
$$

with $a_{h} \quad$ empirical coefficient [-]

$b_{h} \quad$ empirical coefficient [-]

$a_{h}$ is equal to the $y$-axis intercept of the regression curve. For wave steepnesses $s_{m-1,0}$ of about 0.025 and a dike slope of $\tan \alpha=1 / 6$ a freeboard height of $R_{c}=0 \mathrm{~m}$ leads to a flow depth on seaward side of

$$
\mathrm{h}_{2 \%}^{*}=\frac{\mathrm{h}_{2 \%}}{\mathrm{H}_{\mathrm{s}}} \cdot \sqrt{\frac{\mathrm{s}_{\mathrm{m}-1,0}}{\tan \alpha}}=\frac{\mathrm{h}_{2 \%}}{\mathrm{H}_{\mathrm{s}}} \cdot \sqrt{\frac{0.025}{\frac{1}{6}}}=0.39 \cdot \frac{\mathrm{h}_{2 \%}}{\mathrm{H}_{\mathrm{s}}}
$$

and

$$
\mathrm{h}_{2 \%}^{*}=\mathrm{a}_{\mathrm{h}} \cdot \exp \left(\mathrm{b}_{\mathrm{h}} \cdot 0\right)=\mathrm{a}_{\mathrm{h}}
$$


Consequently the flow depth can be given as

$$
\mathrm{h}_{2 \%}=\mathrm{H}_{\mathrm{s}} \cdot \frac{\mathrm{a}_{\mathrm{h}}}{0.39}
$$

For a supposed relation of

$$
\mathrm{h}_{2 \%} \approx 0.5 \cdot \mathrm{H}_{\mathrm{s}}
$$

a constant $y$-axis intercept $a_{h}$ of 0.2 has been derived.

First of all a decreasing flow depth is noticeable for increasing dimensionless freeboard height. Additionally, the higher the angle of wave attack is the lower is the flow depth on the dike crest for unchanged dimensionless freeboard height $\mathrm{R}_{\mathrm{c}}{ }^{*}$. This trend corresponds to former investigations in the influence of the obliqueness of the waves in wave run-up and wave overtopping (cf. Bornschein 2012, Lorke 2012).

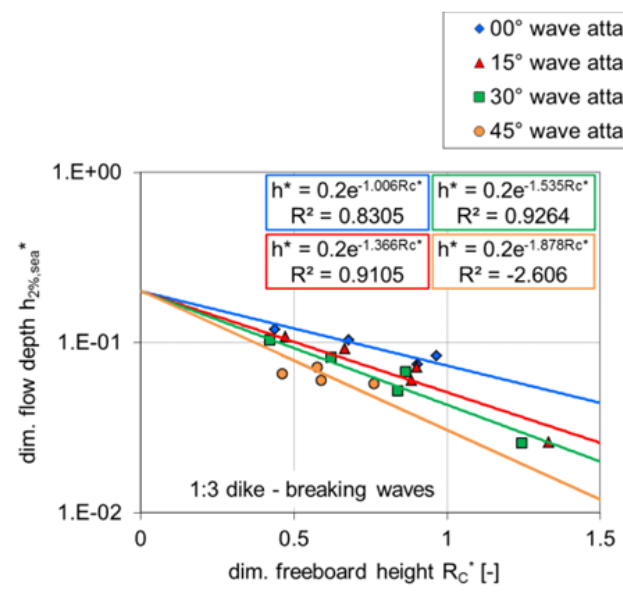

Figure 12. Dimensionless flow depth against dimensionless freeboard height for different angles of wave attack; left: 1:3 sloped dike; right: 1:6 sloped dike.

The inclination of the regression curves is an indication for the quantity of the influence of the angle of wave attack on the flow depth. The higher the inclination is the higher is the reduction of the flow depth due to the analysed influence factor (here: angle of wave attack). In order to compare the influence of the angle of wave attack, an influence factor defined as the quotient of the inclination of the graph of the reference test $b_{\text {ref }}$ and the inclination of the graph $b_{\beta}$ for every investigated angle of wave attack has been derived:

$$
\gamma_{\beta}=\frac{\mathrm{b}_{\mathrm{ref}}}{\mathrm{b}_{\beta}}
$$

These influence factors are plotted in Figure 13 for flow depths (left) and flow velocities (right) against the angle of wave attack. The figures show the influence factors considered for calculating the flow depths and flow velocities on the seaward side of dike crests. The influence factors of flow depths for the 1:3 sloped dike are lower than for the 1:6 sloped dike. This means that on the 1:3 sloped dike the flow depths decrease more significant while increasing the angle of wave attack than on the 1:6 sloped dike. Inconsistent influence factors are given for the tests on 15 degrees wave attack. The formula of the regression curves is given for an equal y-axis intercept of 1.0 as follows:

$$
\begin{array}{ll}
1: 3 \text { sloped dike: } & \gamma_{\beta}=-0.011 \cdot \beta+1.0 \\
1: 6 \text { sloped dike: } & \gamma_{\beta}=-0.008 \cdot \beta+1.0
\end{array}
$$

with $\beta \quad$ angle of wave attack $\left[{ }^{\circ}\right]$

No clear tendency is noticeable for the influence factors on flow velocities. 

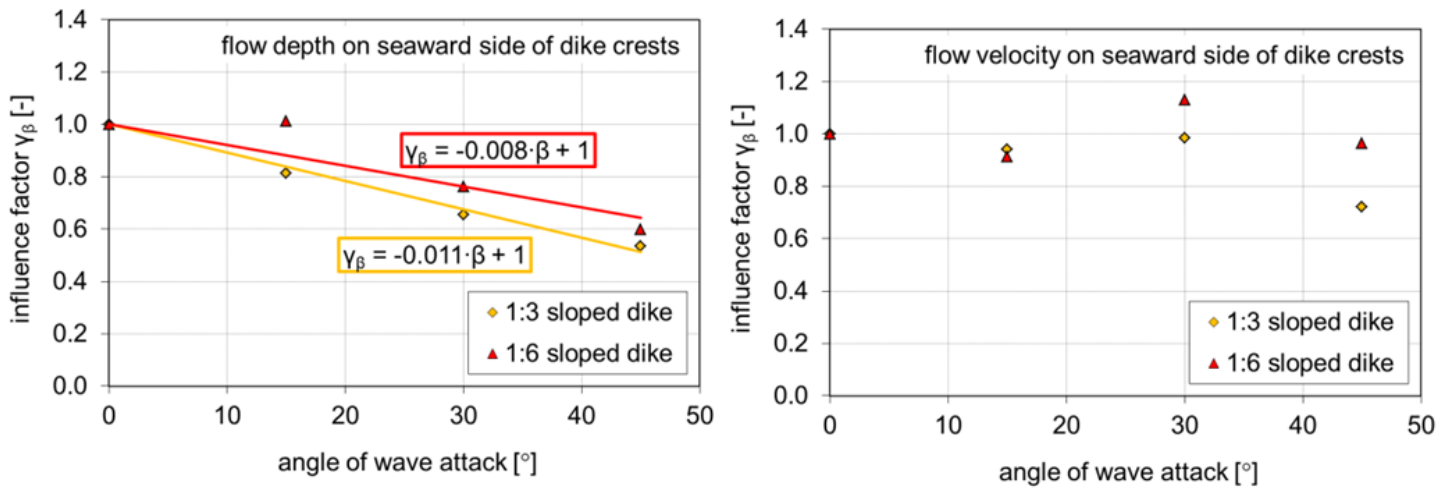

Figure 13. Angle of wave attack against influence factors on flow depth (left) and flow velocity (right) on seaward side of the dike crest.

\section{WAVE-CURRENT INTERACTION}

A new aspect in the introduced study was not only the detailed analysis of flow processes on dike crests influenced by oblique wave attack. Moreover, the influence of a longshore current on wave runup and wave overtopping and therefore, on the presented flow processes has been investigated.

As presented in Lorke et al. (2010) an angle of wave energy, which is a combination of the angle of wave attack and a longshore current has been introduced. Figure 14 shows schematically the combination of the two vectors for the longshore current and the wave direction for negative (left) and positive (right) angles of wave attack. The dashed arrow describes the relative direction of the wave attack generated by the wave generator and the corresponding angle $\beta$. The dotted arrow indicates the direction of the longshore current parallel to the dike line. According to Holthuijsen (2007) the current does not change the angle of wave attack but its energy direction by the combination of the two vectors current velocity $\mathrm{v}_{\mathrm{x}}$ and relative group velocity $\mathrm{c}_{\mathrm{g} \text {,rel }}$ marked with the corresponding arrow. As shown in Figure 14, negative angles of wave attack lead to a smaller absolute value of the angle of wave energy $\beta_{\mathrm{e}}$ whereas positive angles of wave attack lead to a higher angle of wave energy $\beta_{\mathrm{e}}$ than the angle of wave attack $\beta$.

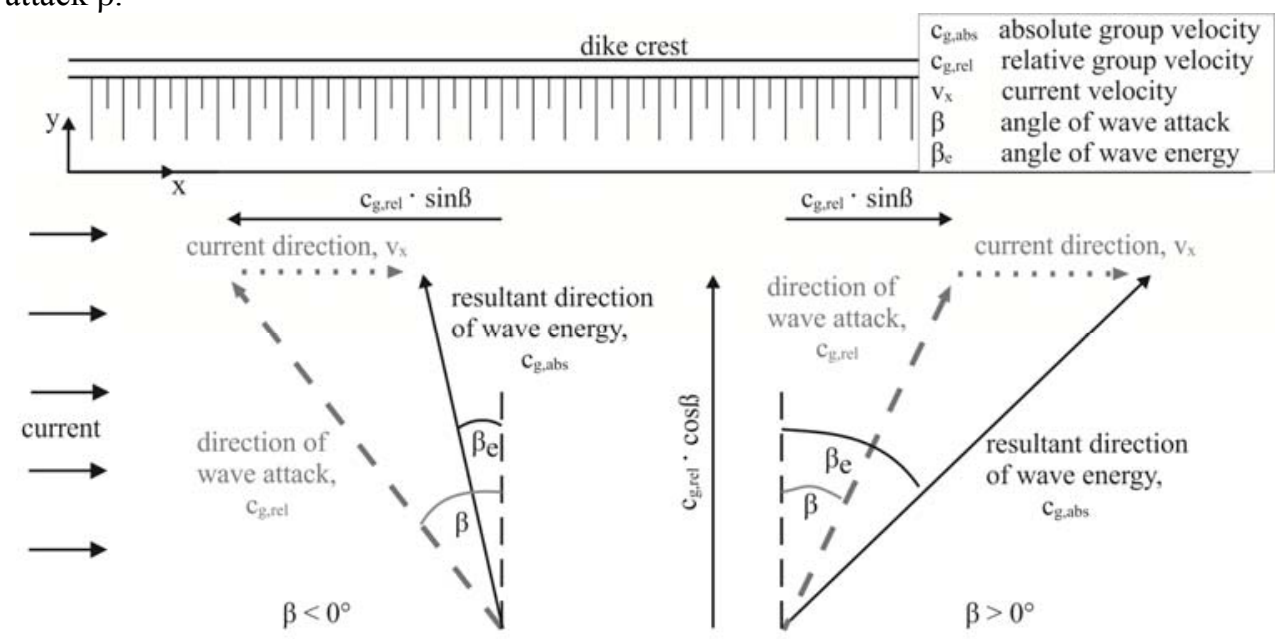

Figure 14. Interaction between wave direction and current (Lorke et al. 2012).

\section{INFLUENCE OF SPATIAL EFFECTS ON WAVE OVERTOPPING}

Corresponding to Lorke et al. 2010 the influence factors for oblique wave attack for average wave overtopping rates are plotted in Figure 15. The black graph is the recommended graph by de Waal \& van der Meer (1992) for wave overtopping. The triangles give the influence factors for tests without current. The current influence is given by the circles $(0.15 \mathrm{~m} / \mathrm{s})$, diamonds $(0.30 \mathrm{~m} / \mathrm{s})$ and quadrats $(0.40 \mathrm{~m} / \mathrm{s})$. The graph on the left shows the influence factors against the angle of wave attack. Adopting the angle of wave energy the data points influenced by a current switch to the right and correspond better to the formula by de Waal \& van der Meer (1992) (cf. Figure 15, right). 

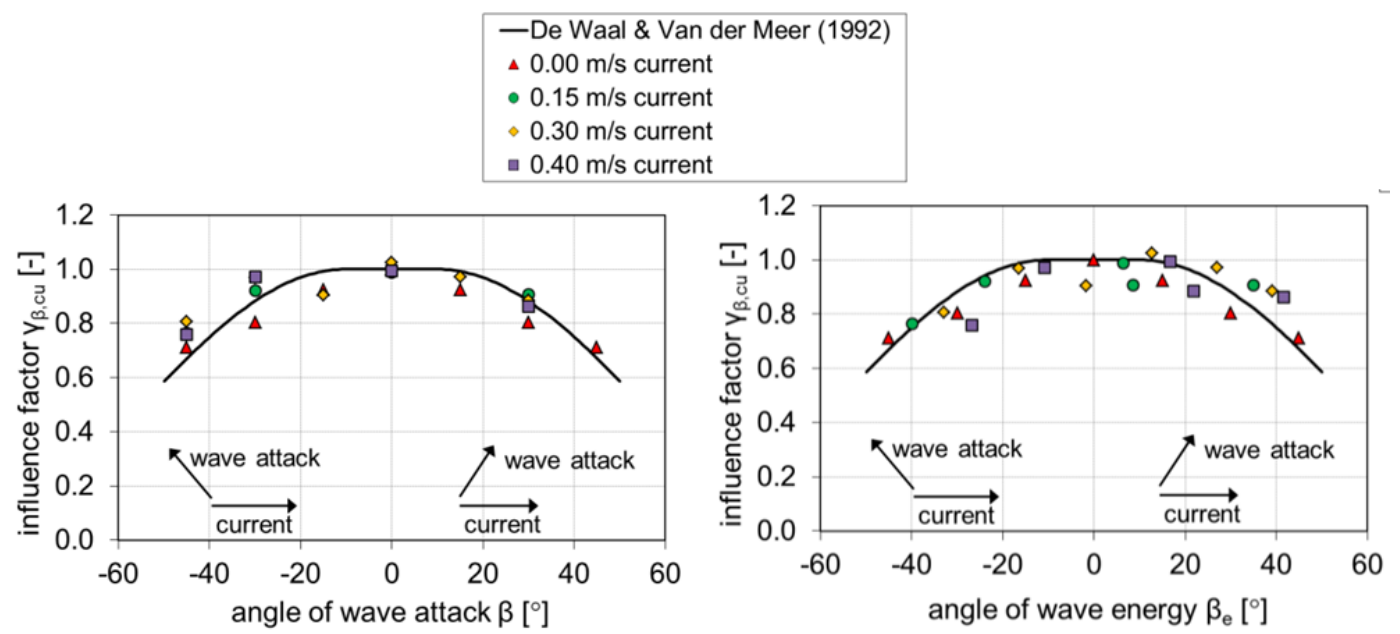

Figure 15. Angle of wave attack (left) and angle of wave energy (right) against influence factors for wave overtopping.

\section{INFLUENCE OF SPATIAL EFFECTS ON FLOW PROCESSES ON DIKES}

Corresponding to the analysis of the influence of the angle of wave attack on flow processes on dikes, the influence of a longshore current will be analysed. Figure 16 shows the dimensionless flow depth against the dimensionless freeboard height on the seaward side of the crest of the 1:6 sloped dike for different current velocities. The regression curves of the data points of the different current velocities with the same $y$-axis intercept have nearly the same gradient. That allows the assumption that no significant influence is noticeable for the influence of a longshore current on the flow depth on the dike crests for perpendicular wave attack. Hence, there is a good agreement with the conclusions of the results on wave overtopping (Lorke et al. 2012). A slightly increasing flow depth is noticeable for a current of $0.40 \mathrm{~m} / \mathrm{s}$ for small relative freeboard heights.

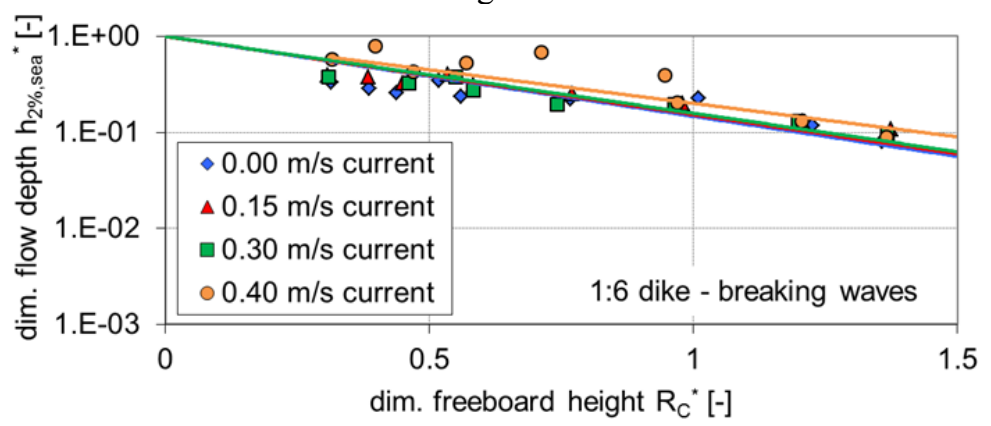

Figure 16. Dimensionless flow depth against dimensionless freeboard height for different current velocities.

Moreover, tests with oblique wave attack and a longshore current have been conducted. The corresponding influence factors, which have been determined in relation to the reference test, are plotted in Figure 17 against the angle of wave attack (left) and against the angle of wave energy (right). The regression of the results of the reference test can be described by the following formula:

1:6 sloped dike: $\quad \gamma_{\beta}=(0.833 \cdot \cos (1.111 \cdot \beta))^{2}+0.307$

with $\beta \quad$ angle of wave attack $\left[^{\circ}\right]$

The correlation coefficient for the reference test is $\mathrm{R}^{2}=0.951$. Considering the tests with a longshore current a correlation coefficient of $\mathrm{R}^{2}=0.453$ has been derived. Introducing the angle of wave energy does not result in much better agreements to the regression curve. The correlation coefficient has been derived $\mathrm{R}^{2}=0.307$. 


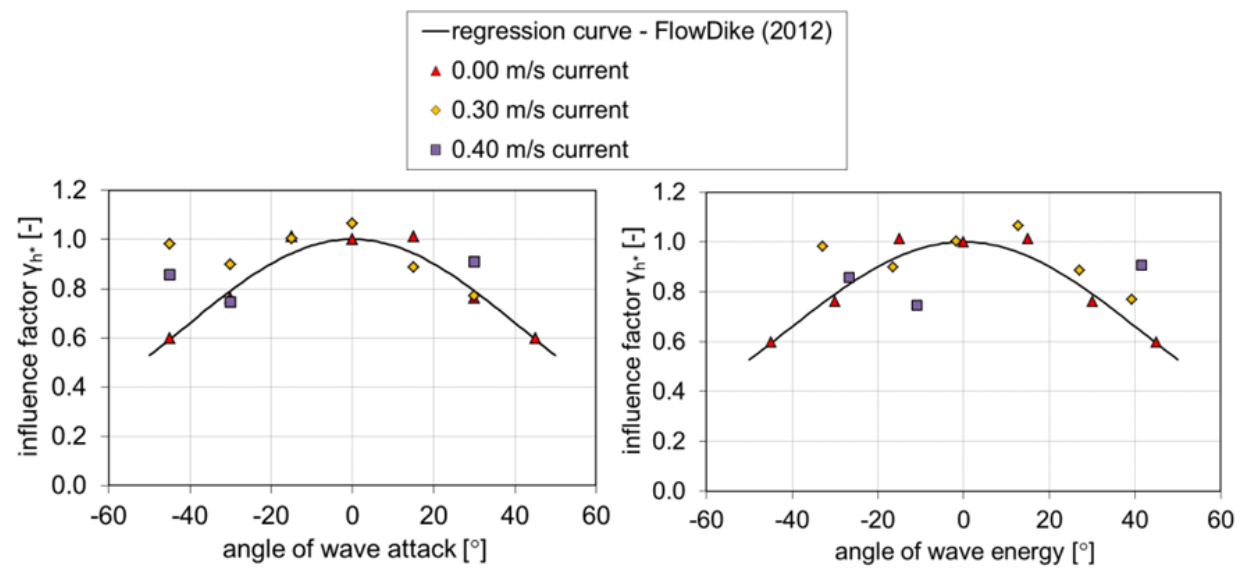

Figure 17. Angle of wave attack (left) and angle of wave energy (right) against influence factors for flow depth on seaward side of dike crests.

\section{CONCLUSIONS}

Physical model tests have been conducted in the shallow water wave basin of the DHI (Danish Hydraulic Institute) in Hørsholm, Denmark. The intention was to get further information on wave runup and wave overtopping at dikes especially on the influences of a longshore current and wind perpendicular to the dike line. The angle of wave attack, the current and the wind velocity were varied during the measurements of wave run-up heights, wave overtopping rates, flow velocities and flow depths on dike slopes and dike crests. Mainly, this paper presents the results on flow depths and flow velocities on dike slopes and dike crests on the 1:6 sloped dike.

Good agreements to investigations by Schüttrumpf (2001), van Gent (2002) and Schüttrumpf \& Oumeraci (2005) for flow depths on dike slopes and dike crests have been depicted. A potential function describing the flow depth along dike slopes could be derived. The flow depths on the seaward side are, depending on the mean dimensionless overtopping rate, about $25 \%$ less than on the seaward slope. The flow depths on the landward side of the dike crest decrease in comparison to the flow depths on the seaward side again by about $30 \%$.

The influence of oblique wave attack on flow depth on dikes can be considered by using an influence factor. The relationship between the angle of wave attack and the influence factor can be described by a linear function. Thereby, the flow depth decreases while increasing the angle of wave attack, which is comparable with results on investigations on wave run-up and wave overtopping (de Waal \& van der Meer 1992, EurOtop-Manual 2007).

The angle of wave energy has to be used to consider the influence of a longshore current on wave overtopping rates and flow depth on dike crests. To consider this spatial effect the influence factor for oblique wave attack on flow depth on dikes has to be adapted by considering the angle of wave energy.

\section{ACKNOWLEDGMENT}

Project FlowDike-D was financially supported by the German Ministry of Education and Research (BMBF) within a KFKI-project (German Coastal Engineering Research Council - GCERC/KFKI, project-no.: 03KIS075 (RWTH Aachen University) and 03KIS076 (TU Dresden)).). The authors thank the staff of the Danish Hydraulic Institute (DHI) in Hørsholm (Denmark) for their scientific support during the test phases and for providing access to the hydraulic laboratory during the Hydralab-project FlowDike (no. HyIII-DHI-5) and the KFKI-project FlowDike-D.

\section{REFERENCES}

Bornschein, A.; Pohl, R.; Lorke, S. (2012): Wave run-up on dikes. In: 5th SCACR 2011 - International Short Conference on Applied Coastal Research: Honouring Prof. Robert A. Dalrymple; 6th to 9th June, 2011, RWTH Aachen University, Germany; proceedings / ed. by H. Schüttrumpf [et al.]. pp. 121-128; http://www.iww.rwth-aachen.de/fileadmin/internet/scacr/SCACR_2011_Proceedings.pdf

Bosman, G. 2007. Velocity and flow depth variations during wave overtopping, Master Thesis, Delft University of Technology. Delft, The Netherlands.

Bosman, G., van der Meer, J., Hoffmans, G., Schüttrumpf, H., Verhagen, H. J. 2008. Individual overtopping events at dikes. ASCE, 31st International Conference on Coastal Engineering 2008, Proceedings ICCE 2008, Hamburg, Germany, p. 2944-2956. 
de Waal, J. P., van der Meer, J. W. 1992. Wave runup and overtopping on coastal structures. Proceedings of the 23rd International Conference on Coastal Engineering, pp. 1772 - 1784

EurOtop-Manual. 2007. Pullen, T., Allsop, N. W. H., Bruce, T., Kortenhaus, A., Schüttrumpf, H., van der Meer, J. W. Die Küste - EurOtop - Wave Overtopping of Sea Defences and Related Structures: Assessment Manual, Issue 73, URL: http://www.overtopping-manual.com/eurotop.pdf (04-18-12).

Holthuijsen, L. H. 2007. Waves in oceanic and coastal waters. Cambridge Univ. Press. United Kingdom.

Lorke, S., Brüning, A., van der Meer, J., Schüttrumpf, H., Bornschein, A., Gilli, S., Pohl, R., Schlüter, F., Spano, M., Riha, J., Werk, S. 2010. On the effect of current on wave run-up and wave overtopping. ASCE , 32nd International Conference on Coastal Engineering 2010, Proceedings ICCE 2010. Shanghai, China.

Lorke, S., Bornschein, A., Schüttrumpf, H., Pohl, R. 2012. Influence of wind and current on wave runup and wave overtopping. Final report 2012. Dresden and Aachen, Germany.

Schüttrumpf, H. 2001. Wellenüberlaufströmung bei Seedeichen - Experimentelle und theoretische Untersuchungen. Dissertation an der TU Braunschweig, Germany.

Schüttrumpf, H., Oumeraci, H. 2005. Layer thicknesses and velocities of wave overtopping flow at seadikes. Journal of Coastal Engineering Vol. 52, Issue 6. pp. 473-495

Schüttrumpf, H., van Gent, M. R. A. 2003. Wave overtopping at seadikes. ASCE, Proceedings Coastal Structures 2003, p. 431-443. Portland, Oregon.

van Gent, M. R. A. 2002. Wave overtopping events at dikes, Proceedings of the 28th International Conference on Coastal Engineering. pp. 2203-2215. Cardiff, United Kingdom. 